\title{
Los Cayos Dinosaur Tracksite: An Overview on the Lower Cretaceous Ichno-Diversity of the Cameros Basin (Cornago, La Rioja Province, Spain)
}

\author{
J. J. Moratalla \\ Instituto Geológico y Minero de España (Museo Geominero), Madrid, Spain
}

\section{J. Hernán}

Escuela Técnica Superior de Ingenieros de Minas, Madrid, Spain

\author{
S. Jiménez \\ Iberdrola, Sección de Mineralogía y Paleontología, Bilbao, Spain
}

\begin{abstract}
The Los Cayos dinosaur tracksite is located at the eastern sector of the Cameros Basin (Cornago Township, La Rioja province), NE Spain. The sediments consist of interbedded terrigenous siliciclastics and carbonates belonging to the Enciso Group (Early Cretaceous, Aptian in age). The sedimentological and faunal evidence suggests that these sediments were deposited in a low gradient lacustrine environment.

Los Cayos constitutes a relatively wide area with at least 6 localities that have yielded dinosaur tracks. More than 2,000 dinosaur tracks have been discovered to date. Medium to large theropod dinosaurs constitute about $95 \%$ of the ichnofauna. Ornithopod dinosaur tracks have been reported from only one of the outcrops (Los Cayos D). Los Cayos S has yielded theropod and sauropod tracks. One sauropod trackway shows a narrow-gauge locomotion pattern and a manus print morphology suggesting that the trackmaker was a titanosaurid, or at least a titanosauriform sauropod. Some pterosaur manus impressions, avian-like footprints of small size and possible turtle tracks complete the assemblage of one of the most impressive and best-preserved dinosaur tracksites of the European Lower Cretaceous.
\end{abstract}

Keywords Paleoichnology, dinosaurs, aves, turtles, pterosaurs, Lower Cretaceous, Cameros Basin, Spain

\section{INTRODUCTION}

The Cameros Basin is located in the northwestern part of the Iberian Range and includes part of the Spanish provinces of $\mathrm{La}$ Rioja, Soria and Burgos (Fig. 1A). The basin area is c. 8000

Address correspondence to J. J. Moratalla, Instituto Geológico y Minero de España (Museo Geominero), Ríos Rosas, 23, 28003 Madrid, Spain. E-mail: j.mortalla@igme.es $\mathrm{km}^{2}$, and the thickness of the stratigraphic section has been calculated at about $9000 \mathrm{~m}$ (see Geological Setting section for further details). These estimations suggest that the Cameros sequence represents a wide geographical area during a relatively long span of time, approximately 35 million years, through the Late Jurassic to the Early Cretaceous.

More than 150 dinosaur track areas have been already identified. However, most of them contain several outcrops, and each outcrop normally shows several track-bearing layers, making the number of these layers difficult to estimate. The consequence of such an abundance of tracksites is not only a tremendous number of individual dinosaur footprints (more than 6000 estimated individual tracks) but also a great potential ichno-diversity. Since the first scientific studies by Casanovas and Santafé, (1971, 1974) were published, abundant technical (Sanz et al., 1985; Moratalla et al., 1988a; Moratalla et al., 1988b; Moratalla and Sanz, 1992; Moratalla et al., 1992; Moratalla, 1993; Moratalla et al., 1994a; Moratalla et al., 1994b; Lockley et al., 1995; Fuentes, 1996; Casanovas et al., 1997; Moratalla et al., 1997; Moratalla and Sanz, 1997; Lockley et al., 1998a; Pascual and Sanz, 2000; Moratalla, 2002, etc.) and popular papers (Moratalla et al., 1989; Moratalla et al., 1997; Sanz et al., 1997) have shed light on several aspects about Cameros paleoichnology.

The Cameros area was a relatively active basin with a high subsidence rate and thick sediment accumulation. The presence of relatively extended areas dominated by sand and mud, the existence of an environment of relatively low energy conditions, and the intense activity of dinosaurs led to the production and especially the preservation of abundant dinosaur tracks. Moreover, the Cameros Basin was a land connection between 


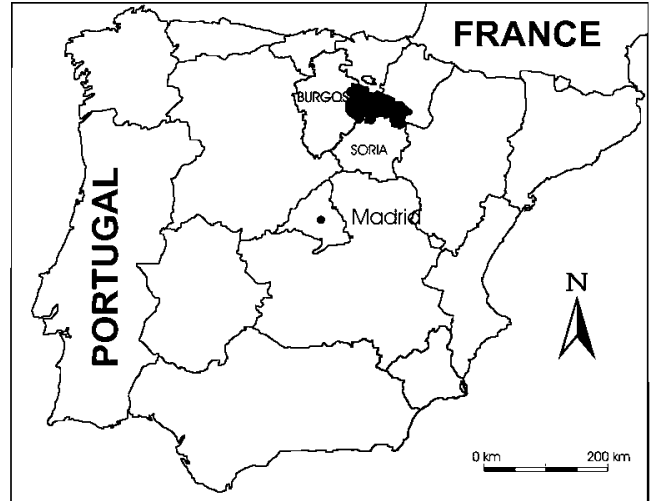

A

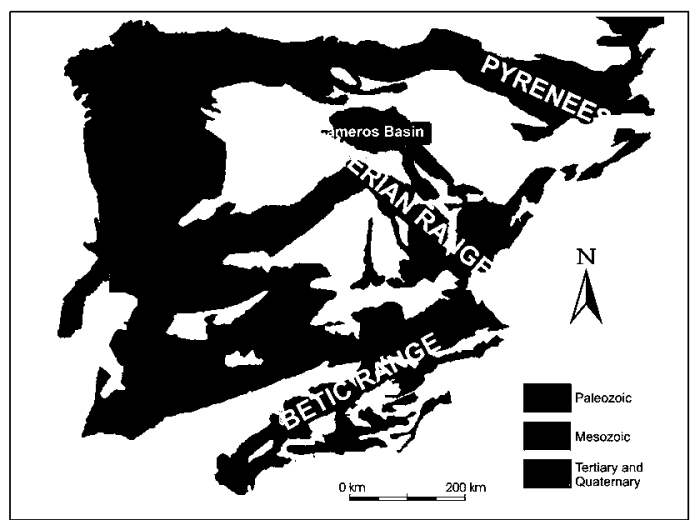

B

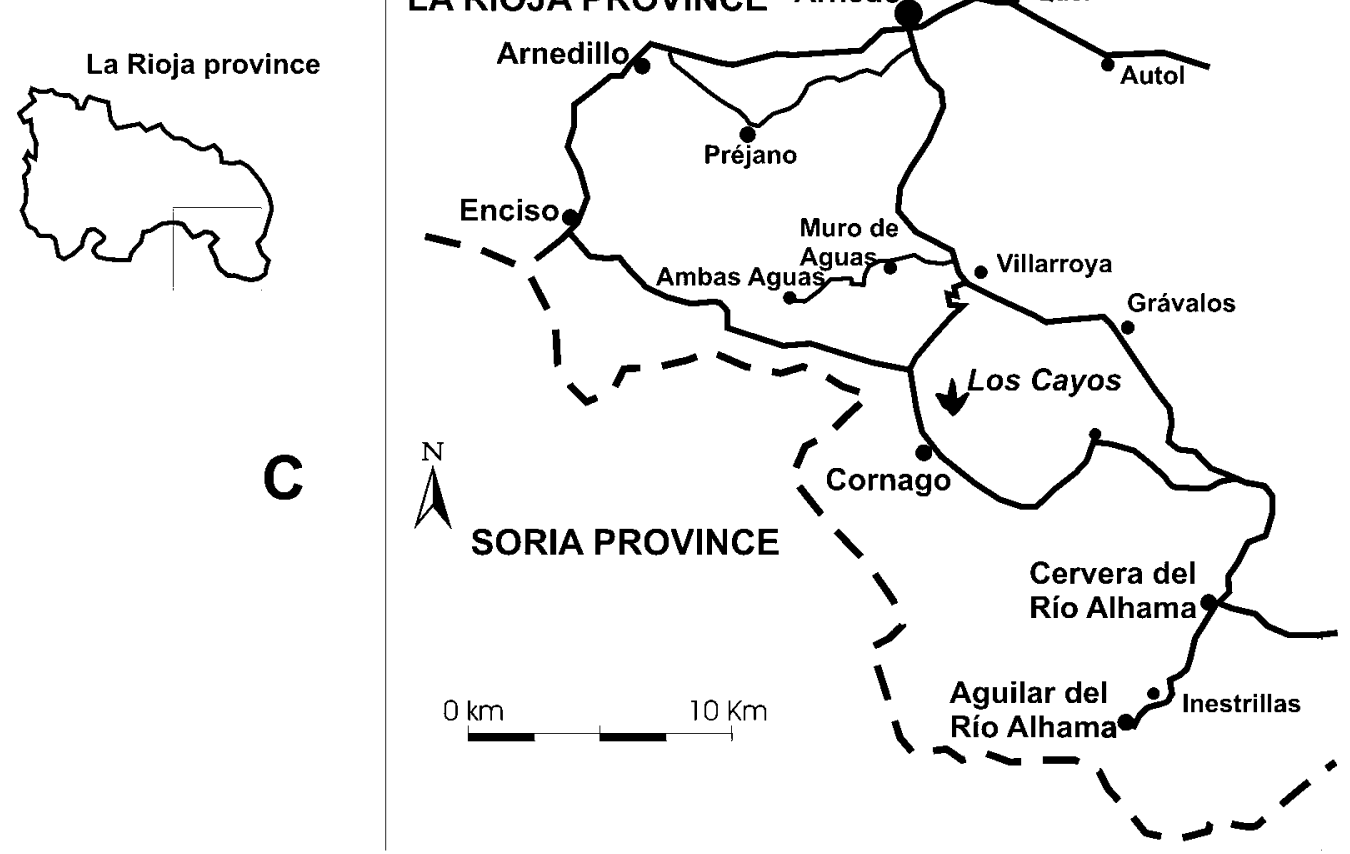

FIG. 1. A. Map of the provinces of La Rioja, Soria and Burgos. B. Geological sketch of the Iberian Peninsula with the location of the Cameros Basin. C. Location map of the Los Cayos tracksite.

the Iberian Massif and the Ebro Massif, especially during Aptian times. The aim of this paper is to review the vertebrate tracks of the Los Cayos locality as an example of the Lower Cretaceous Cameros Basin.

\section{GEOLOGICAL SETTING}

The Cameros Basin is one of the rift basins of Late Jurassic to Early Cretaceous age in the northwestern most part of the Iberian Range. The Iberian Range is an intraplate belt located between two main alpine ranges, the Pyrenees to the north and the Betic Range to the south (Fig. 1B). The Cameros Basin is atypical within the context of the Iberian Range basins due to its high subsidence and sedimentation rates and because it is the only one in which part of the infill has been affected by metamorphism (Mas et al., 1993; Casquet et al., 1992; Barrenechea et al., 1995; Alonso Azcárate et al., 1995). The sedimentary sequence of the Cameros Basin comprises deposits of continental origin (fluvial and lacustrine systems) with sporadic marine incursions.

The Cameros Basin can be divided into two sub-basins: Western Cameros and Eastern Cameros, each with a rather different stratigraphic framework (Mas et al., 1993; Martín-Closas and Alonso, 1998). Several lithostratigraphic schemes have been proposed for the Upper Jurassic-Lower Cretaceous conti- 
nental sequence of the Eastern Cameros sub-basin. Tischer (1966) performed the first important stratigraphic study of this sub-basin and defined five lithological groups: Tera, Oncala, Urbión, Enciso, and Oliván (Fig. 2). Subsequently, other authors have modified this scheme with varying degrees of success (Salomon, 1982a, b; Guiraud, 1983; Guiraud and Seguret, 1985). The present stratigraphic scheme is based on a Late Jurassic-Early Cretaceous megasequence bounded by two main unconformities (Tithonian and early Albian), which can be further subdivided into six depositional sequences (namely DS1 to DS6) separated by minor unconformities (Mas et al., 1993) (Fig. 2).

The dinosaur tracksites are abundant in this sub-basin (DS1, DS3, DS5 and DS6) (Fig. 2), and the Los Cayos tracksite is located in the Enciso Group (DS5). The Enciso Group was deposited only in the Eastern Cameros sub-basin and displays a complex organization marked by strong lateral and vertical facies changes, which record a complex mosaic of lacustrine deposits interbedded with minor fluvial deposits.

The Enciso Group at Los Cayos Creek (Fig. 3) consists of a mixture of interbedded terrigenous and carbonate deposits. It is interesting to note that all the footprints in this area occur at the top of siliciclastic beds and appear to be associated with symmetrical ripples, bioturbation and mud cracks.

Fine-grained sediments dominate the terrigenous deposits of grayish and brown claystones and siltstones and fine to medium grained micaceous sandstones. Most of the rocks are massive or mottled, but some units are laminated or cross-laminated. The absence of channelized deposits and erosional surfaces rules out the presence of significant fluvial channels in the area and suggests that the clastic input into the lake was mostly by sheet flood. These siliciclastic units are interpreted as lacustrine deltas and mudflats developed in a nearshore lake environment. Also, they represent either floodplain deposits, which record the supply of fine-grained deposits onto the exposed nearshore lake surface during low lake stands.

On the other hand, the carbonate deposits comprise wellbedded dark limestones and marlstones rich in ostracods (minor sandy and marly limestones also occur). The predominance of mudstone and wackestone textures suggests low-energy sedimentation. The general absence of lamination in the carbonates implies bioturbation of the sediments, and the black color in

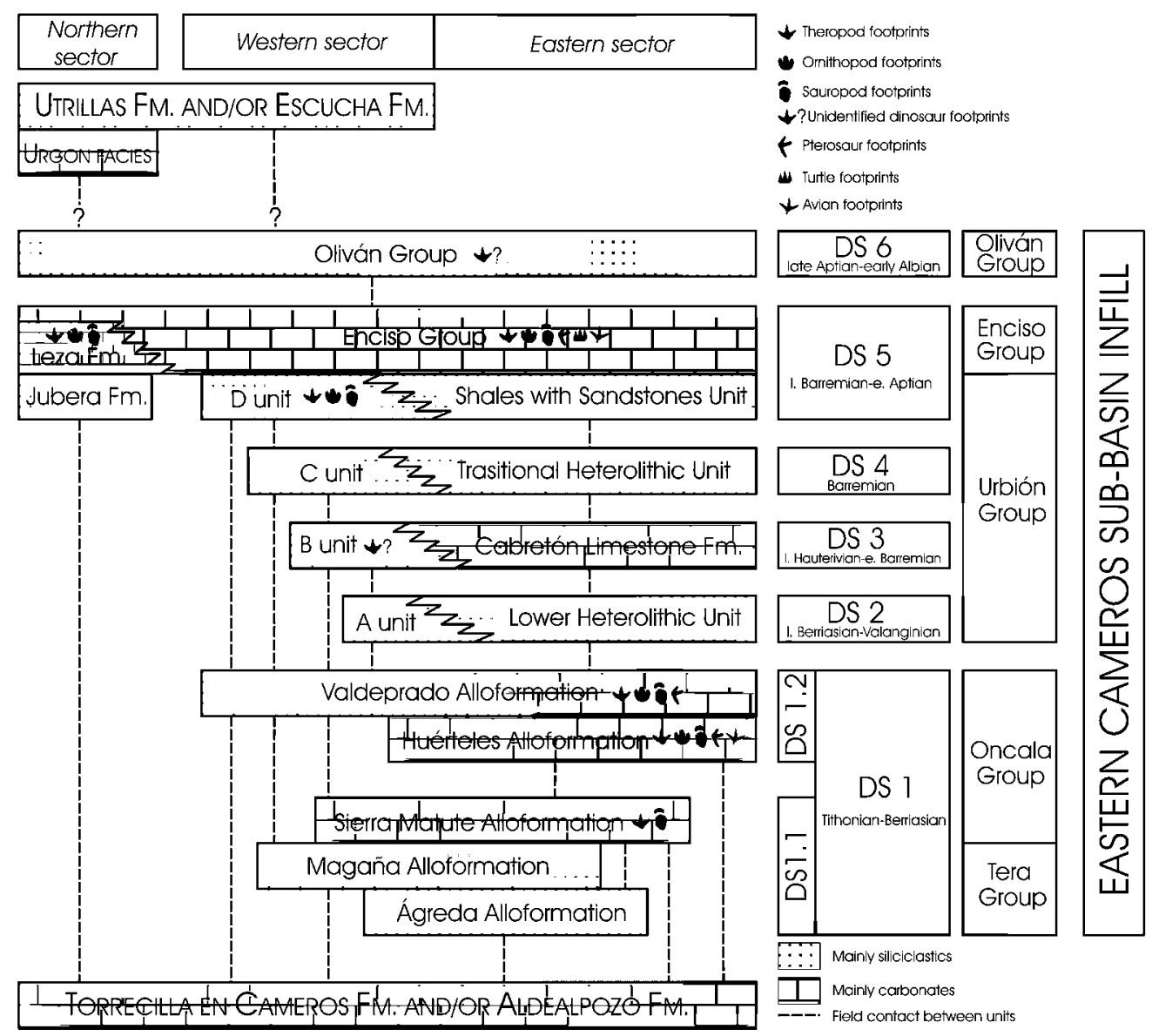

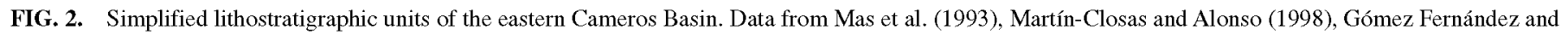

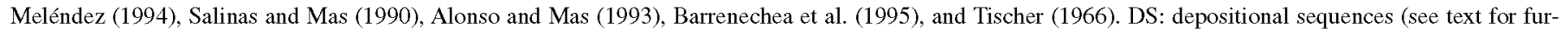
ther details). The different length of the boxes does not imply areal extent. 

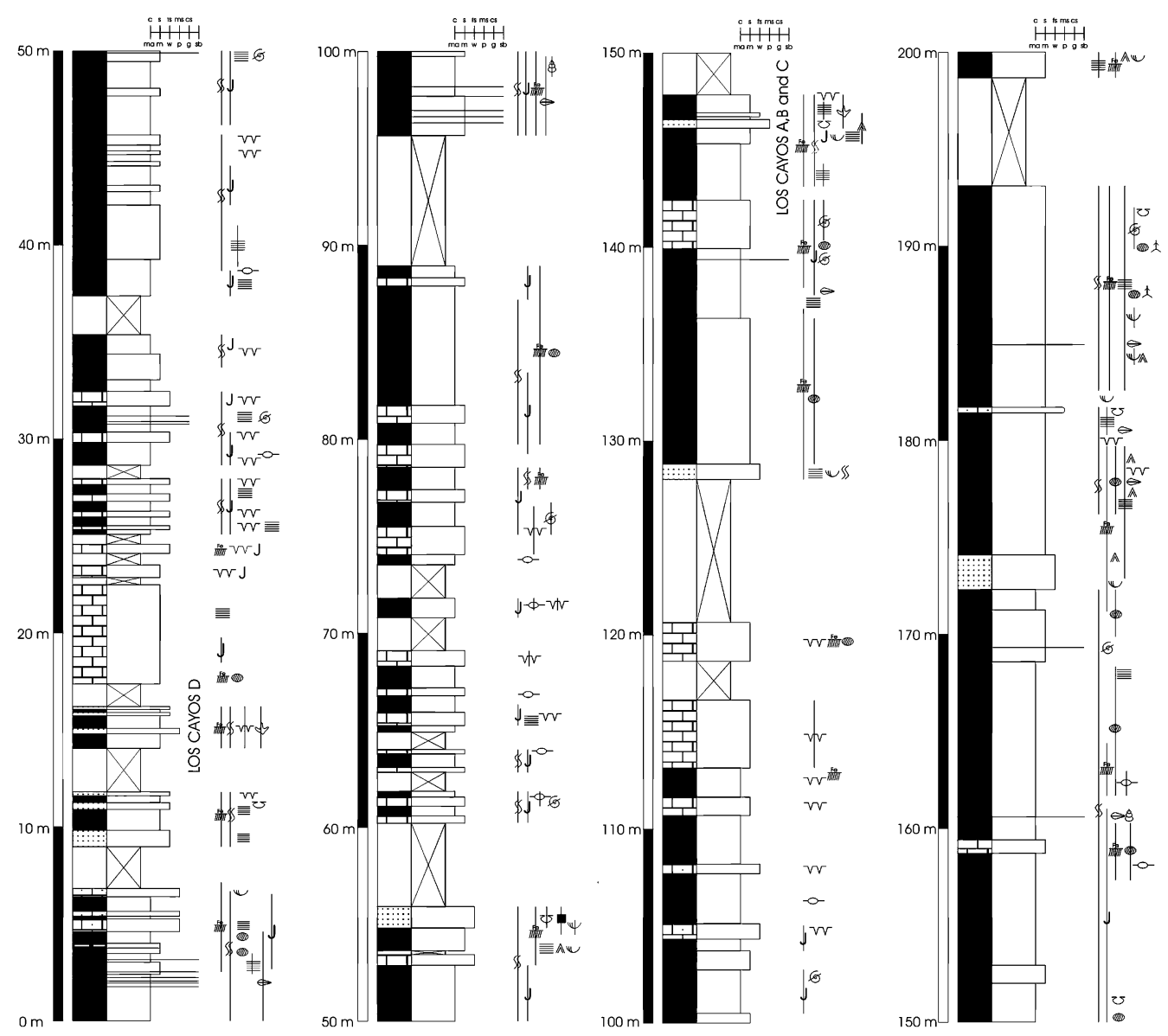

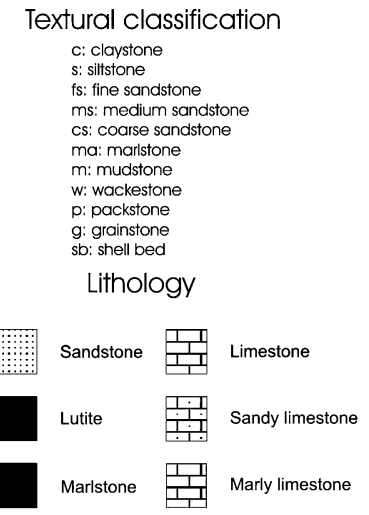

Sedimentary structures

U Trough cross lamination

II Planar cross lamination

Parallel lamination

A Symmetrical ipp

NV Mud-cracks

Im Nodules

fid
finlin

$\circlearrowright$ Load structures

- Pyrite

Organic structures

Bioturbation

d) Dinosaur footprints

太 Roots

Fossil fragments

8 Gastropods

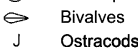

FIG. 3. Stratigraphic series of the Los Cayos area, showing the location of Los Cayos A, B, C, and D. Los Cayos S is situated about $100 \mathrm{~m}$ below Los Cayos $\mathrm{D}$, while Los Cayos E is located about $150 \mathrm{~m}$ above Los Cayos B.

lacustrine limestone may be due to the presence of organic matter and/or pyrite. These carbonate units are interpreted as being deposited in a lacustrine environment with low gradient and low energy margins ("ramp margins," Tucker and Wright, 1990; Platt and Wright, 1991). These lake marginal zones were extensive, and so small-scale water level fluctuations caused subaerial exposure of large areas (sensu Freyret, 1984). Some carbonate beds can also be interpreted as pond or marsh deposits developed over the floodplain surrounding the shallow lakes.

Mud-cracks, bioturbation, nodules, ripples, and ferruginous crusts are common into both lithologies. The presence of these structures indicates shallow depths and subaerial exposure of the beds, but their preservation rules out pedogenic reworking. Lack of well-developed paleosols and the preservation of lamination indicate very short emergent times.

The faunal evidence consists entirely of freshwater-brackish elements typical of lacustrine environments. Fossils are locally abundant, commonly appearing as shell beds, consisting of ostracods (Cypridea, Darwinula, and Theriosynoecum), gastropods (Paraglauconia), and bivalves (Unio and Eomiodon). Scarce plants fragments (Tempskya, charophytes) also occur (Brenner, 1976; Calzada, 1977; Mennessier and Calzada, 1985; Barale and Viera, 1989).

\section{LOS CAYOS TRACKSITE}

The Los Cayos site is located about $1.5 \mathrm{~km}$ north of Cornago town, La Rioja province, Spain (see Fig. 1C), and constitutes a relatively wide area with at least 6 dinosaur track outcrops named Los Cayos A, B, C, D, E, and S. The different outcrops are distributed throughout a relatively thick stratigraphic column, about $500 \mathrm{~m}$ (see the central part of Los Cayos stratigraphy in Fig. 3). Most of the tracks were made by dinosaurs, specifically theropods (Los Cayos A, B, C, E and S), ornithopods (Los Cayos D), and sauropods (Los Cayos S).

In addition, isolated pterosaur tracks are present at Los Cayos A and Los Cayos C, and possible turtle tracks and tiny avian-like footprints also occur at Los Cayos C. These records represent a relatively high diversity compared with other Cameros tracksites that only show dinosaur tracks.

\section{Theropod Tracks}

Theropod tracks represent the largest percentage (about 95\%) of the entire Los Cayos assemblage. They are distributed throughout Los Cayos A, B, C, E, and S (Fig. 4).

Eight track-bearing layers form Los Cayos A. The most significant is level A7 (Fig. 6A), representing a stratigraphic surface of about $1200 \mathrm{~m}^{2}$ (Fig. 5). The footprints are up to $10 \mathrm{~cm}$ 


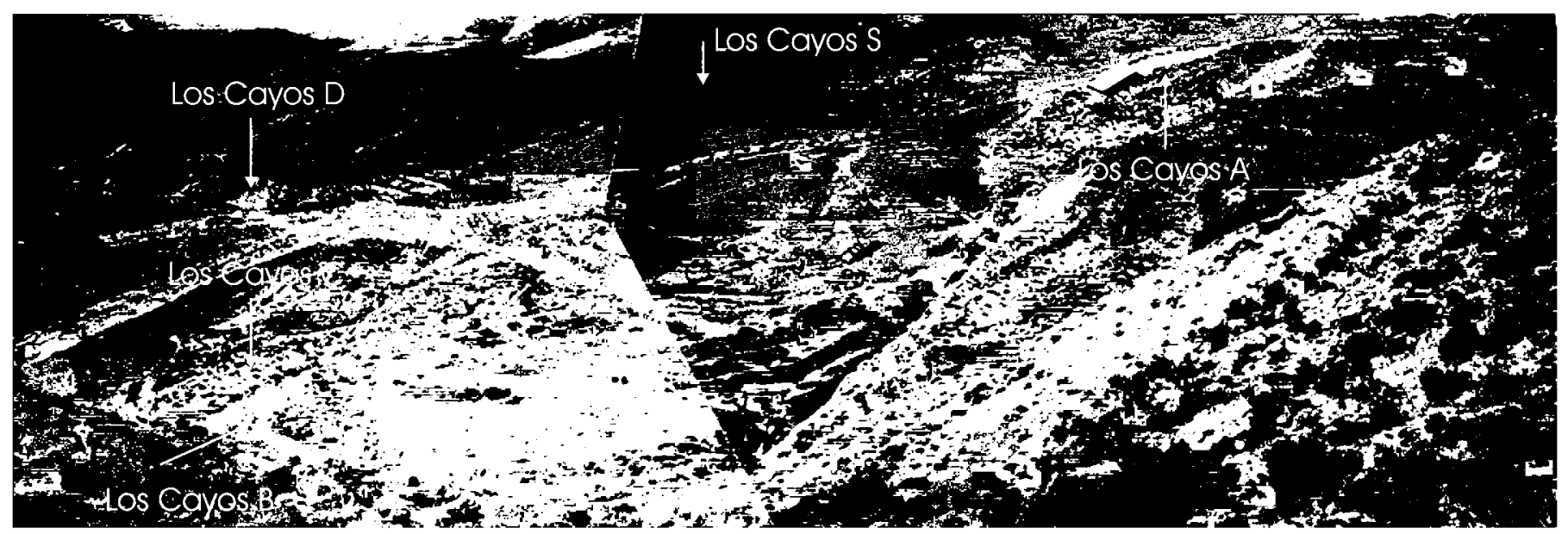

FIG. 4. Los Cayos area (Cornago, La Rioja, Spain) showing the location of the different outcrops. The photo was taken from Los Cayos E.

deep and relatively well preserved. Although some of the dinosaur tracks are filled by sediment from the overlying layer, most of them are clear and well-defined natural molds. The best-preserved tracks (Fig. 5) are covered by a roofed protection financed by the Iberdrola Co. in the 1980s (Figs. 4 and 5).

Despite some morphological variability in shape and size, most of the tracks show relatively common characters, suggesting that the same dinosaur group had made all of them. There are 193 dinosaur footprints arranged in 36 trackways. The longest one contains 11 tracks, and an additional 232-isolated tracks complete the assemblage at this outcrop. This represents a total of 425 well-preserved dinosaur tridactyl tracks.

The best-preserved trackway is LCA-R3 consisting of 11 footprints (Fig. 6B). Footprint number four (LCA-R3/4) (Fig. $6 \mathrm{C}$ ) is particularly well preserved. The length (FL) of this track is $44 \mathrm{~cm}$ and the width (FW) is $42 \mathrm{~cm}$; thus the ratio FL/FW is 1.07. The digit impressions are relatively broad, robust, and with pointed distal ends. The central digit (III) is clearly Vshaped, and slightly medially curved. Digit II is also medially

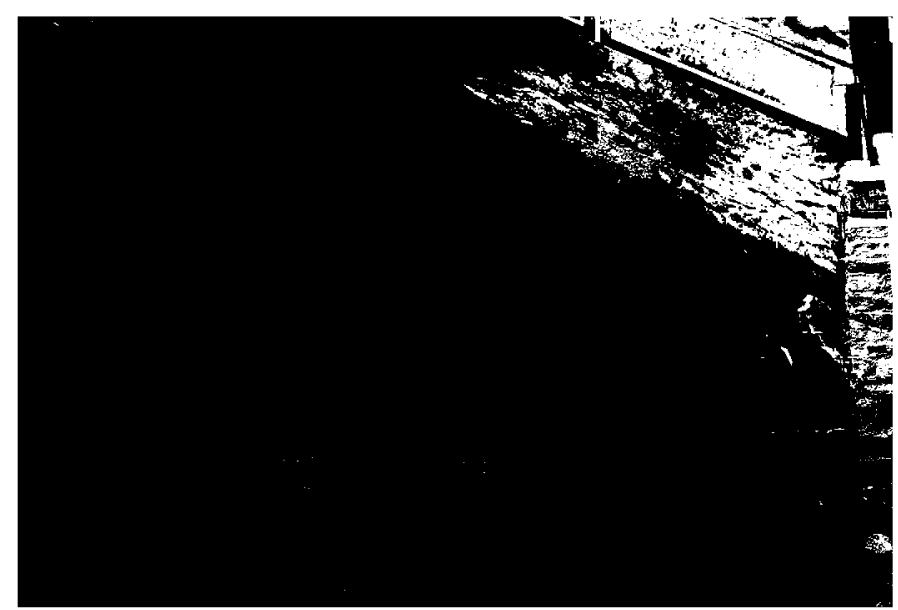

FIG. 5. Some parallel theropod trackways inside the protective hut at Los Cayos A (level A7).
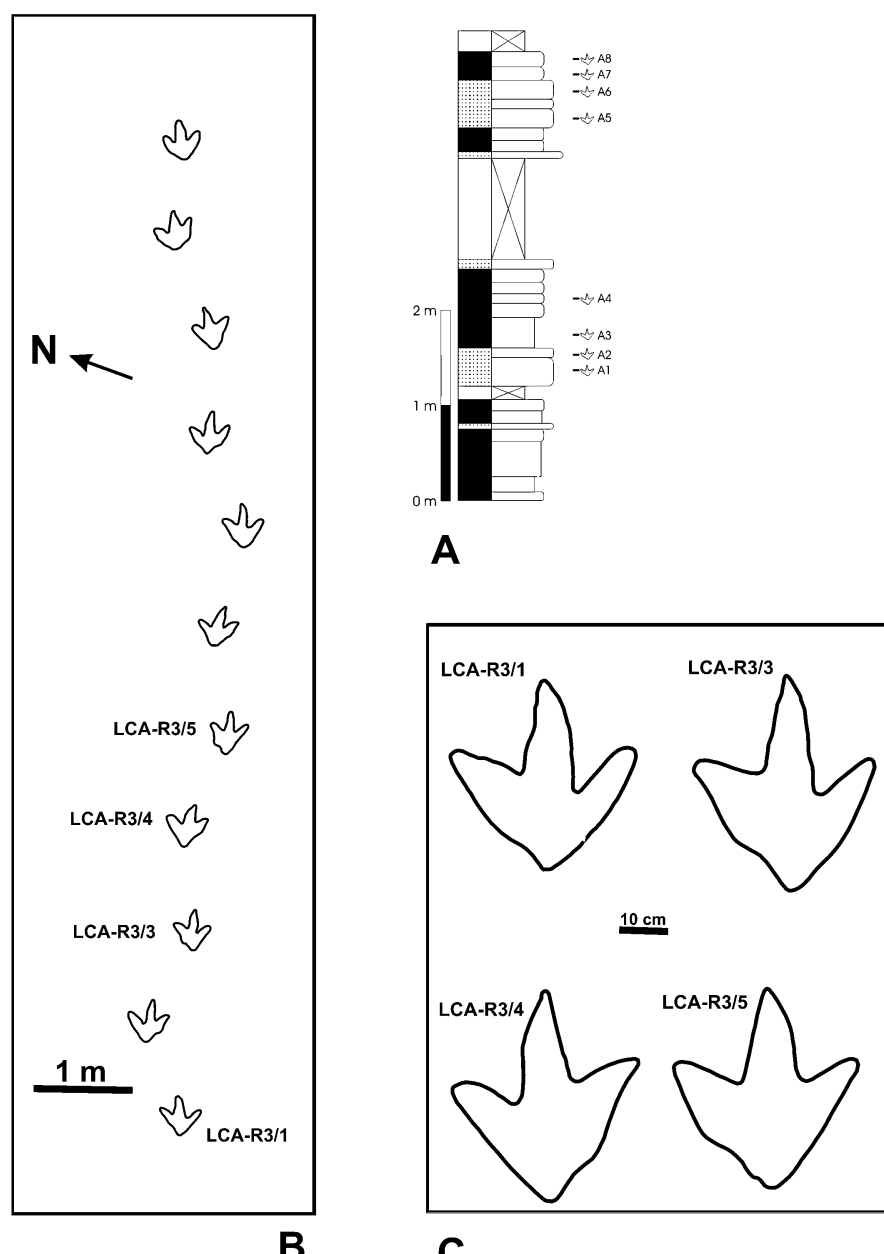

C

FIG. 6. A. Stratigraphic section of the Los Cayos A showing all the trackbearing layers. B. Map of the best-preserved dinosaur trackway (LCA-R3) at Los Cayos A (level A7). The length of the footprints shows a mean value of $42.9 \mathrm{~cm}$. C. Detail of the best-preserved footprints. 


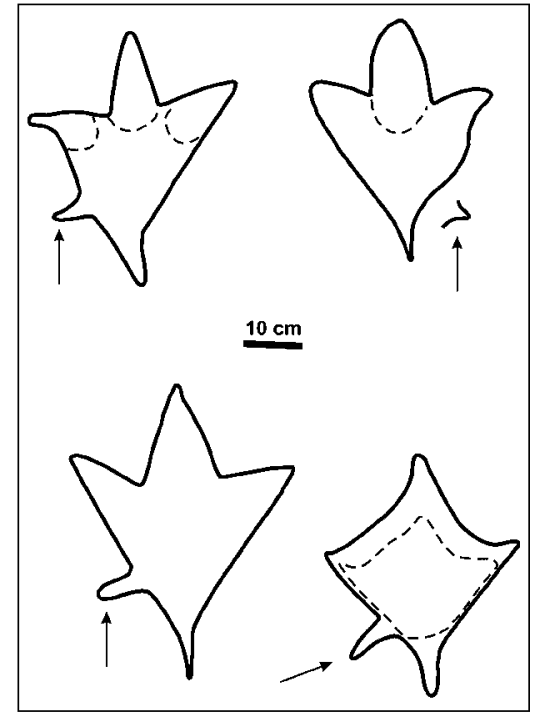

FIG. 7. Theropod tracks from Los Cayos A (level A7) showing the impression of the hallux in the medial margin of the print. The arrow indicates the hallux impression. curved whereas digit IV shows a more straight and lateral orientation. Both interdigital angles are broadly similar ( $32^{\circ}$ for II-III, and $35^{\circ}$ for III-IV), but the medial hypex is located more distally than the lateral one. Although the heel outline is relatively backward elongated, the heel surface is wide and extended, showing a slight medial indentation. This track shows a maximum depth of $6 \mathrm{~cm}$. The deepest areas are located on the digit III and on the heel. This is a typical biomechanical consequence for a mesaxonic foot.

Although more than $90 \%$ of the theropod tracks at Los Cayos are tridactyl, some of them show the impression of the hallux, that is, they are tetradactyl (Fig. 7). Moreover, these footprints frequently show a posteriorly elongated heel, but they are not significantly deeper than those tridactyl ones. This fact suggests that the impression of the hallux could be caused by the trackmaker taking a crouched stance. This implies a lower position of the hallux touching the substrate during the step. This is a good example showing that the morphology of a dinosaur track depends mainly on locomotion or posture factors (Vecchia and Tarlao, 2000). This general track morphology described above for Los Cayos A can be extended to the other Los Cayos outcrops (Los Cayos B, C, E, and S).
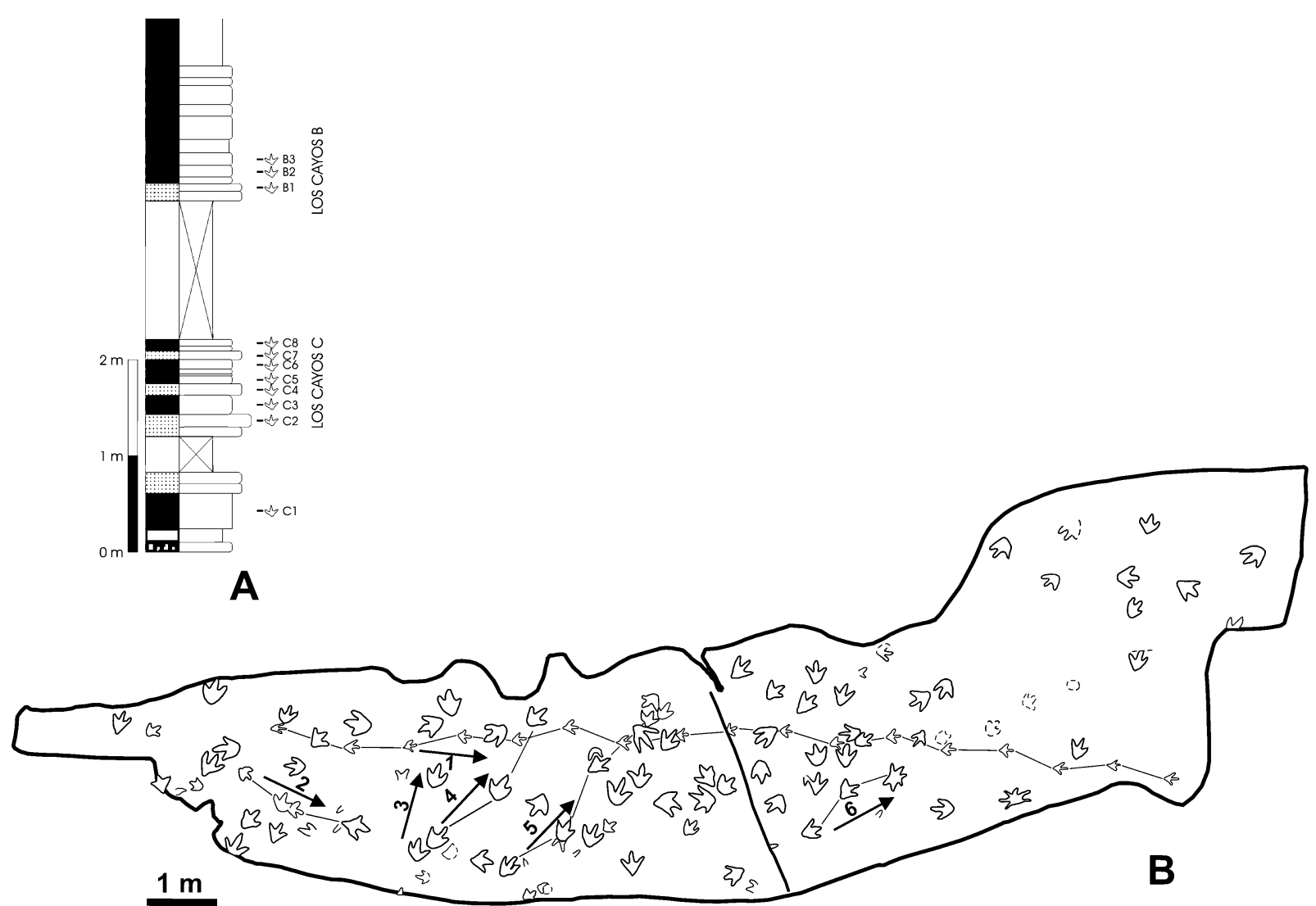

FIG. 8. A. Stratigraphic section of Los Cayos B and C showing the different track-bearing layers. B. Map of one of the exposures at the Los Cayos B outcrop (level B3) showing an impressive trackway (Number 1) formed by 17 very small theropod footprints. The number and the arrows indicate the different trackways. 

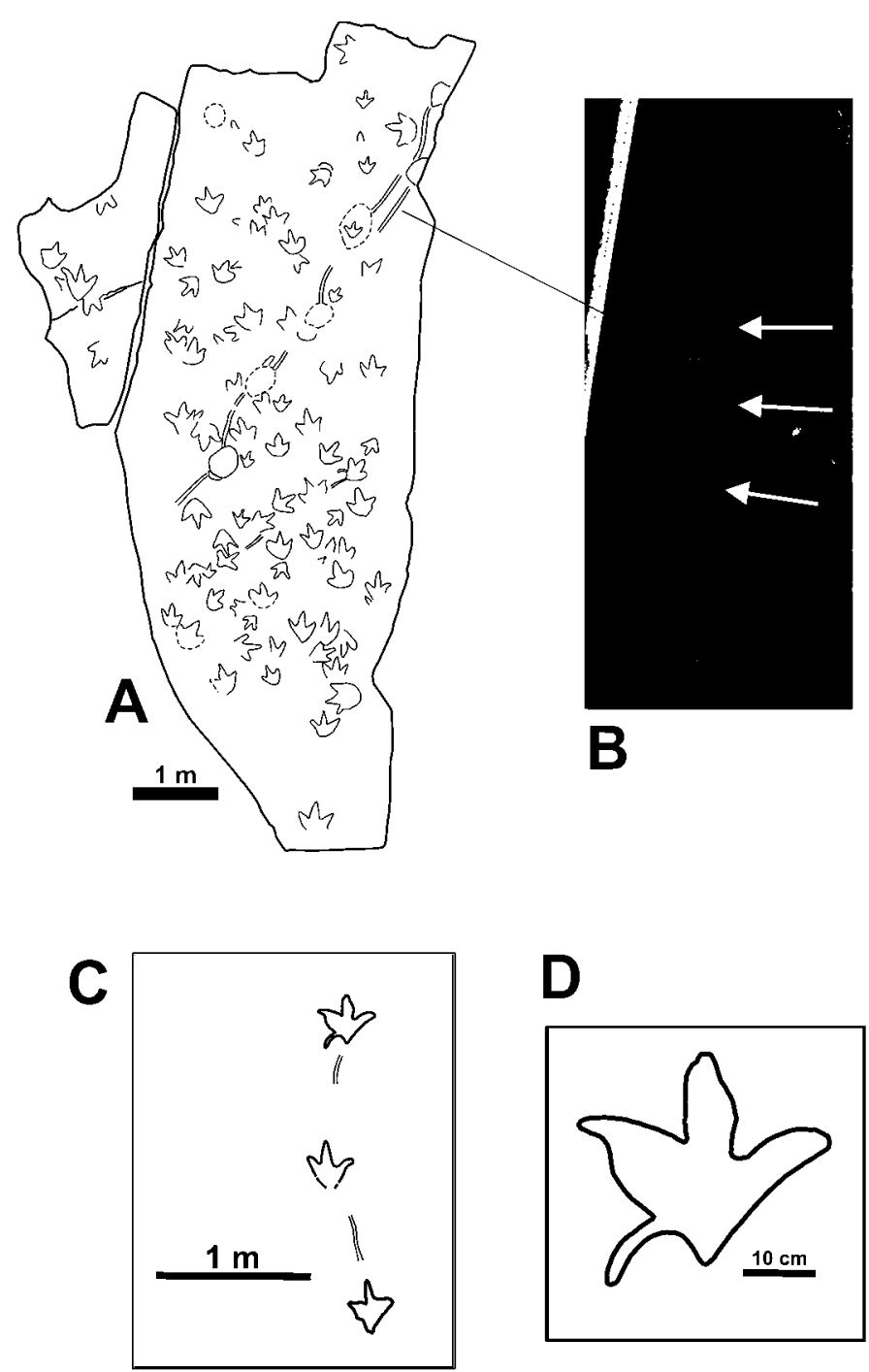

FIG. 9. A. Map of one the exposures of level B3 at Los Cayos B. B. Photo of a possible dinosaur tail drag. C. Theropod trackway showing a possible $2 \mathrm{~cm}$ wide tail drag. D. Detail of the third footprint of the former trackway.

Los Cayos B has yielded many dinosaur tracks on three main levels. Level B1 (Fig. 8A) constitutes a surface of c. 450 $\mathrm{m}^{2}$ with about 250 tridactyl footprints, 69 of them arranged in 10 trackways. The main one, LCB1-R2, consists of 18 tracks preserved is a relatively fine-grained sandstone. On the contrary, tracks in level B3 are preserved in a very fine-grained siltstone.

Although most of level B3 tracks are of medium to large size, some of the trackways show smaller footprints, between $18-22 \mathrm{~cm}$ in length. Seventeen consecutive and well-preserved footprints form the most extensive trackway (Fig. 8B, trackway 1). The morphology of these tracks shows some differences with respect to the larger ones, such as rounded distal digit ends, parallel outline of digit III, more symmetrical heel outline, smaller heel surface, etc. Although we consider them as having been made by theropod dinosaurs, progress is being made on determining whether these and the medium to big dinosaur tracks belong to juvenile and adult individuals, respectively.

Two theropod trackways (another sector of level B3) have preserved possible tail drag impressions (Fig. 9). This feature is not common in the dinosaur paleoichnological record. The pattern of this tail drag is sinusoidal, with a relatively narrow furrow going from one track (i.e., left) to the next one (i.e., right). This pattern of locomotion is expected for a bipedal dinosaur, since the tail was probably used as a counterbalance, with slight right to left movement during each step (Moratalla et al., 1992).

Despite some variation in the preservation, size, and shape of the Los Cayos theropod tracks, most of them share similar basic features suggesting that a similar type of theropod dinosaur produced them. Moratalla (1993) identified the Los Cayos theropod tracks as Buckeburgichnus Abel 1935, although Lockley et al. $(1996,1998$ a) reasigned them to Megalosauripus. A more detailed analysis on the variability, morphology, and interpretation of the Cameros theropod tracks is now progressing. Only one trackway and some isolated footprints at Los Cayos $\mathrm{C}$, consisting of narrow footprints with low interdigital angles and well-defined pad impressions, were identified as Therangospodus (Moratalla, 1993; Lockley et al., 1998b). Whether Megalosauripus or Buckeburgichnus is more appropriate, the evidence suggests that two theropod dinosaurs with a different acropodial structure (narrow and wide) were responsible for the Los Cayos theropod footprints.

\section{Ornithopod Tracks}

Up to now the only outcrop with ornithopod footprints is Los Cayos D. It consists of a bioturbated surface of about 130 $\mathrm{m}^{2}$ of siltstone (level D4, Fig. 10A). About 90 dinosaur tracks were studied and measured. The sediment of the overlying strata covers some tracks. Most of the tracks are isolated, and do not form part of recognizable trackways. Only one welldefined trackway consisting of three consecutive large and deep footprints has been identified. The tracks show very short pace and stride values (stride length: $157 \mathrm{~cm}$ ), with an inward rotation of about $10^{\circ}$.

Some of the footprints are very deep suggesting that the animals stepped on waterlogged mud. The length of the best-preserved footprints is about $50-60 \mathrm{~cm}$. The digits are broad, short, and distally rounded, and the third digit (central) is clearly U-shaped. The footprints are characterized by a wide and broad heel surface (Fig. 10B), and they have symmetrical indentations on both medial and lateral sides.

These morphological features suggest that these dinosaur tracks were made by ornithopods, specifically by iguanodontids, which are very abundant in the European Lower Cretaceous (Norman, 1980; Norman, 1986; Santafé et al., 1982; Sanz et al., 1982; Sanz et al., 1984a, 1984b, 1984c; Sanz, 1986; Santafé and Casanovas, 1990; Sanz et al., 1990; Santafé and Casanovas, 1993). No manus prints or tail drags have been discovered at Los Cayos D. 

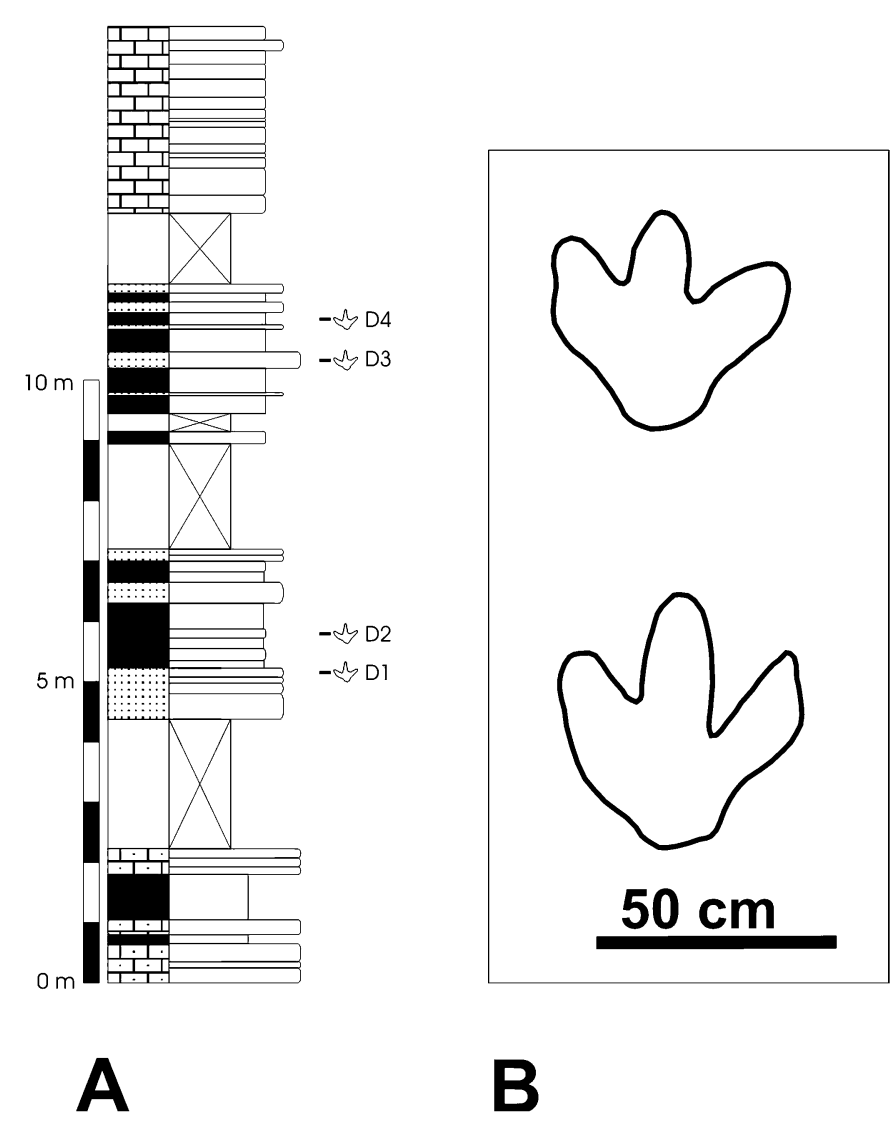

FIG. 10. A. Stratigraphic section of Los Cayos D showing the different trackbearing layers. B. Two ornithopod footprints from Los Cayos D (level D4).

\section{Sauropod Tracks}

Los Cayos $\mathrm{S}$ is the only locality that has yielded sauropod tracks. Of the 12 ichnological levels at this locality, only two show sauropod tracks. The most significant level contains a single trackway formed by 5 prints, 2 of them being pes prints, and 3 belonging to the manus (Fig. 11). The footprints are about 50 $\mathrm{cm}$ in length and about $37 \mathrm{~cm}$ wide. These pes prints are not very well preserved and do not show digit prints. On the contrary, the most interesting features are located at the manus prints. One very well-preserved print is double-crescent shaped, with the concavity directed backward. It has a length of $32 \mathrm{~cm}$ and a width of $35 \mathrm{~cm}$, and the mean depth is about $4 \mathrm{~cm}$. Both digits $\mathrm{I}$ and $\mathrm{V}$ are rounded, although digit $\mathrm{V}$ is slightly broader. The impressions of digits II and IV are clearly visible as outlines. The impression of digit III is broad, about $25 \mathrm{~cm}$ in width, and it constitutes the anterior part of the manus print. The angle between I and $\mathrm{V}$ digit impressions is slightly greater than $270^{\circ}$. This value is the angle formed by the two longitudinal digital axes. The morphology is similar to Titanosaurimanus (Dalla Vecchia et al., 2000).

Most of the dinosaur sauropod trackways reported at Cameros Basin have been identified as the wide-gauge morphotype, Brontopodus (Casanovas et al., 1997). Until now only two sauro- pod tracksites had been identified as narrow-gauge type: Valdemurillo locality (Moratalla et al., 1992) and Las Navillas (Casanovas et al., 1995). Wilson and Carrano (1999), based on the theoretical orientation of titanosaurid femurs, proposed that the wide-gauge sauropod trackways had been made by titanosaurs or at least by titanosauriformes, a conclusion also reached by Day et al. (2002). However, this new sauropod trackway questions this assumption. Although we would need a longer trackway in order to confirm the locomotion pattern, the four preserved tracks of the Los Cayos S sauropod trackway suggest a narrow-gauge locomotion pattern.

Similar sauropod tracks were also described and discussed in the Albian-Cenomanian from Istria (Dalla Vecchia and Tarlao, 2000; Dalla Vecchia et al., 2001). These authors reached a similar conclusion. If this interpretation is correct, the titanosaurid dinosaurs could have produced both narrow and wide gauge trackways. This conclusion agrees with the classical interpretation of Farlow (1992) and indicates the necessity of a revision on the morphology and biomechanics of sauropods.
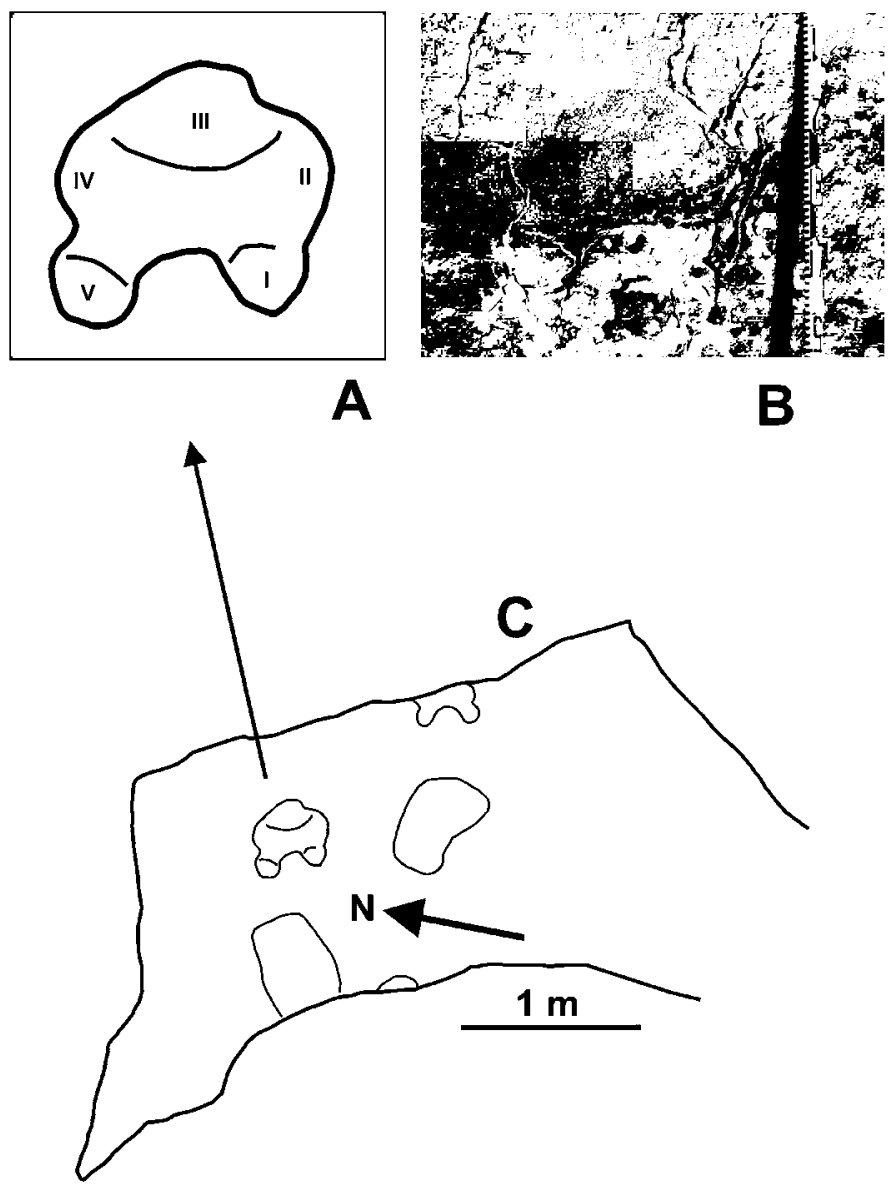

FIG. 11. Trackway (C) and manus print (A, B) of a sauropod at Los Cayos $S$. Note the rounded shape of both digits I and $V$ and the high value of the interdigital angle between these digit marks (see text for further details). 

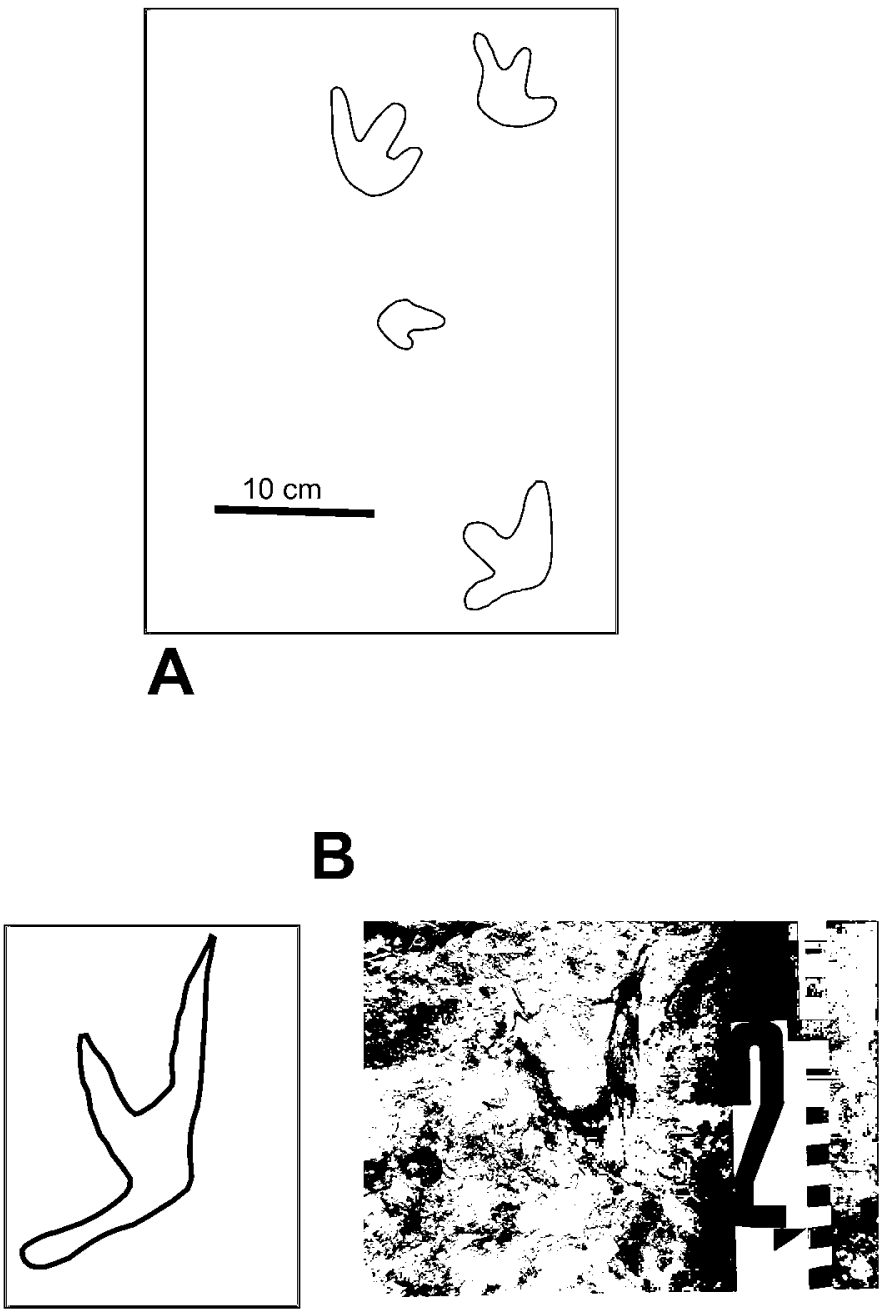

FIG. 12. Pterosaur manus prints at Los Cayos. A. Some isolated Pteraichnus manus prints at Los Cayos A (level A3). B. An isolated manus print at Los Cayos C (level C5).

\section{Pterosaur Tracks}

Both Los Cayos A and C have yielded pterosaur tracks. One slab at Los Cayos A (level A3, Fig. 6A) shows three complete manus impressions and an incomplete one (Fig. 12A). These tracks are isolated, and do not form any recognizable trackway. The Los Cayos C outcrop has yielded only one isolated pterosaur manus impression (Fig. 12B) (level C1, Fig. 8A). The prints are small, tridactyl, and with a high interdigital angle (between $120^{\circ}-130^{\circ}$ ). They are asymmetrical in that the impression of digit III is more acuminate than those of digits I and II. Also the interdigital angle I-II is smaller than that of the II-III. The Los Cayos tracks are similar to those manus prints described by Stokes (1957) and also abundant material attributed to pterosaurs (Lockley et al., 1995). Although the Los Cayos A tracks show blunt distal digit impressions while the Los Cayos C specimen shows an acuminate digit III, the general shape, size, digital dimensions, and interdigital angles suggest that all these tracks have been made by pterosaurs, and we identify them as Pteraichnus.

Pterosaur tracks from the Cameros Basin have been reported at 20 localities by Lockley et al. (1995), Fuentes and Meijide (1996), and Pascual and Sanz (2000). All of them, including the Los Cayos specimens described above, have been identified as Pteraichnus. Most of the prints recorded in the Cameros Basin are manus impressions, and pes prints are rare. Although pterosaur tracks are more abundant in the Huérteles Alloformation (Fig. 2), some pterosaur manus prints and bone fragments have been reported from the Enciso Group (Moratalla et al., 2000). This broad distribution of pterosaur tracks all over the Cameros Basin points to two significant consequences: 1) that the pterosaurs were relatively common in the Cameros ecosystems, and 2) they walked on land probably more than was previously thought.
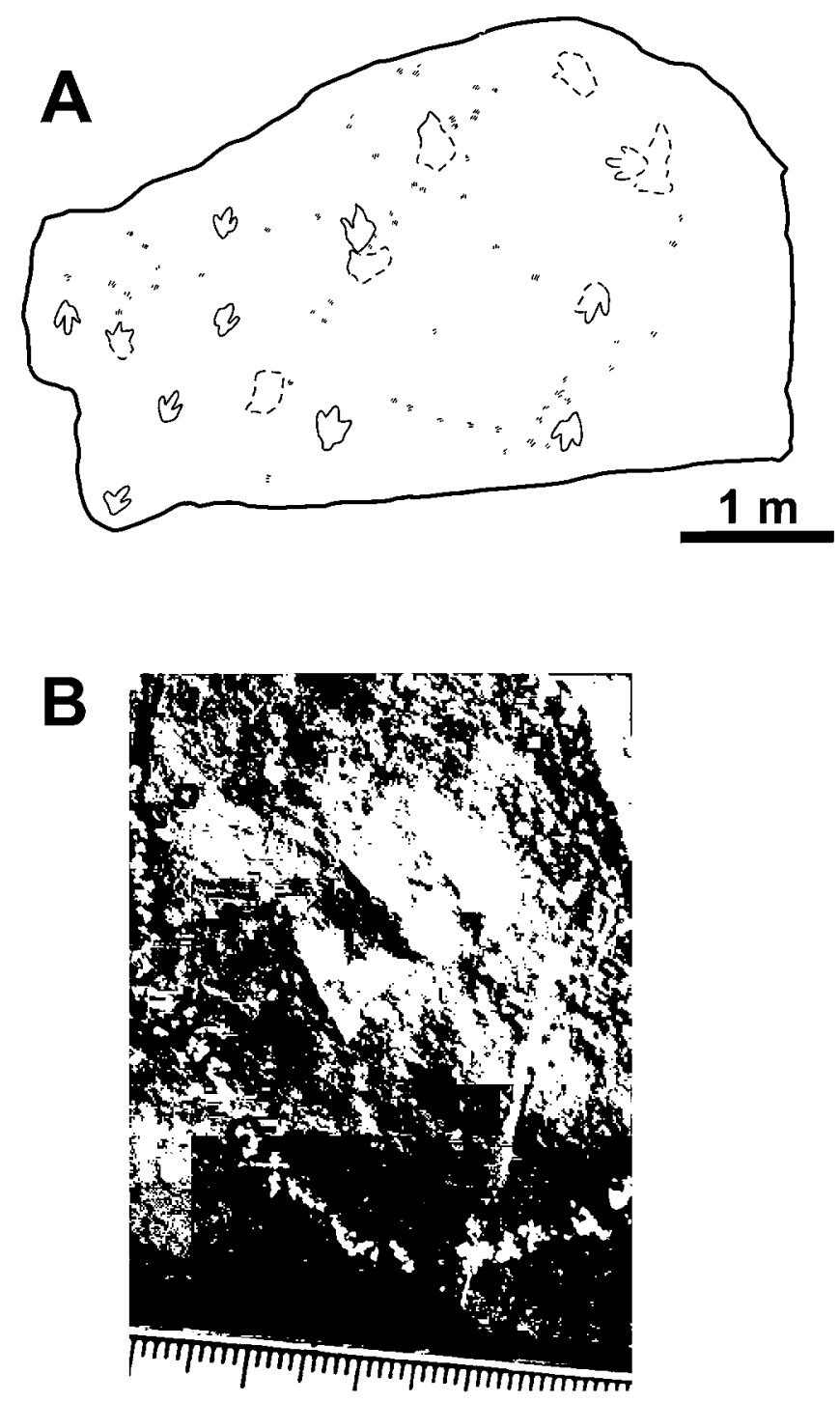

FIG. 13. Theropod and turtle tracks at Los Cayos C (level C5). A. Map of the tracks; B. Detail of one of the turtle impressions. 

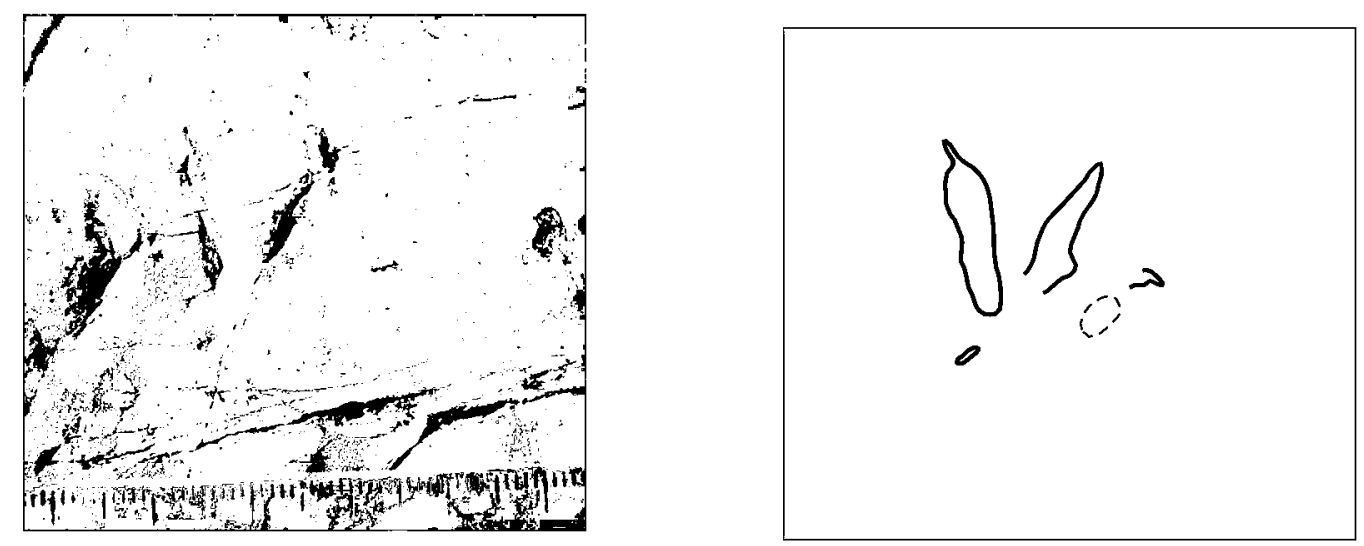

FIG. 14. A tiny avian-like footprint at Los Cayos C (level C5). Note the posterior orientation of the hallux impression suggesting the presence of an avian-like trackmaker.

\section{Turtle Tracks}

One slab (level C5, Fig. 8A) at Los Cayos C (Cornago, La Rioja) tracksite has yielded 58 small prints characterized by longitudinal digit impressions. The size of these prints ranges between 0.5 and $2.5 \mathrm{~cm}$ in length. Most of the tracks are tridactyl, with parallel, longitudinal, unconnected digit marks (Fig. 13). The digit impressions are very slender with the distal end acuminate. Although no definite trackways have been recorded, some of the tracks are aligned, suggesting some kind of directional movement. Moratalla (1993) tentatively interpreted these fossil prints as having been made by turtles. Similar fossil tracks from the Laramie Formation have been interpreted in the same way (Foster et al., 1999; Wright and Lockley, 2001). A closer and complete description and interpretation of these tracks are progressing.

\section{Avian-Like Tracks}

Los Cayos C has also yielded some complete and fragmentary tiny tracks interpreted as avian-like impressions (level C5, Fig. 8A). Although the material is not very well preserved, one of the footprints (Fig. 14) reveals several features considered as avian. The track is about $2 \mathrm{~cm}$ in length, including a possible fully reverted hallux impression. Because the hallux backward rotation is considered an avian character (Chiappe, 1997; Elzanowsky, 2002; Chiappe, 2002), this track was interpreted as produced by an avian dinosaur (Moratalla and Sanz, 1992; Moratalla, 1993).

However, Middleton (2002) suggested that the backward rotation of the hallux is not a synapomorphy of the clade Aves. On the contrary, Archaeopteryx would have an anterior-medially-directed hallux while the Enantiornithes would posses intermediate metatarsal I morphologies; that is, they would have medially directed halluces. If this interpretation is correct, then the backward orientation of Aves halluces was later than the acquisition of active flight capability (Middleton, 2002). More morpho-functional analyses should be carried out in order to discriminate these significant characters.

In any case, the presence of this track and other ichnogenera-like Archaeornithipus (Fuentes, 1996), Ignotornis (Lockley et al., 1992), Koreanornis (Kim, 1969), etc. reveal the presence of avian or avian-like trackmakers with posterior orientation of the hallux during the Lower Cretaceous.

\section{ACKNOWLEDGEMENTS}

I wish to thank to La Rioja Government and Iberdrola Co. for supporting some of the field work. Thanks are also extended to all the volunteers from Arnedo, Préjano, and Cornago towns for their help in the field. Thanks also to Fabio Dalla Vecchia and an anonymous reviewer for their valuable suggestions that have substantially improved the paper. This paper is a result of DGICYT research project number BTE 2001-0185 CO2-01.

\section{REFERENCES}

Abel, O. 1935. Vorzeitliche Lebensspuren. Jena, Gustav Fischer, 644 pp.

Alonso-Azcárate, J., Barrenechea, J. F., Rodas, M., and Mas, J. R. 1995. Comparative study of the transition between very low-grade and low-grade metamorphism in siliciclastic and carbonate sediments: Early Cretaceous, Cameros Basin (Northern Spain). Clay Minerals, 30:407-419.

Alonso, A. and Mas, J. R. 1993. Control tectónico e influencia del eustatismo en la sedimentación del Cretácico inferior de la cuenca de Los Cameros. España. Cuadernos de Geología Ibérica (Estratigrafía del Cretácico de la Península Ibérica I), 17:285-310.

Barale, G. and Viera, L. I. 1989. Tempskya riojana nov. sp. Fougère arborescente du Crétacé inférieur du Nord-ouest de L'Espagne. Palaeontographica Abteilung B, 212:103-122.

Barrenechea, J. F., Rodas, M., and Mas, J. R. 1995. Clay mineral variations associated with diagenesis and low-grade metamorphism of early Cretaceous sediments in the Cameros Basin, Spain. Clay Minerals, 30:119-133.

Brenner, P. 1976. Ostrakoden und Charophyten des spanischen Wealden (Systematik, Ökologie, Stratigraphie, Paläogeographie). Palaeontographica Abteilung A, 152:113-201.

Calzada, S. 1977. Un yacimiento Barremiense en Cameros (Logroño). Boletín de la Real Sociedad Española de Historia Natural (Geología), 75:35-38. 
Casanovas, M. L. and Santafé, J. V. 1971. Ichnites de reptiles mesozoicos en la provincia de Logroño. Acta Geológica Hispánica, 9:45-49.

Casanovas, M. L. and Santafé, J. V. 1974. Dos nuevos yacimientos de icnitas de Dinosaurios. Acta Geológica Hispánica, 9:88-91.

Casanovas, M. L., Ezquerra, R., Fernández, A., Pérez-Lorente, F., Santafé, J. V., and Torcida, F. 1995. Dos nuevos yacimientos de icnitas de dinosaurios en la Rioja y en la provincia de Soria (España). Coloquios de Paleontología, 47:9-23.

Casanovas, M. L., Fernández, A., Pérez-Lorente, F., and Santafé, J. V. 1997. Sauropod trackways from site El Sobaquillo (Munilla, La Rioja, Spain) indicate amble walking. Ichnos, 5:101-107.

Casquet, C., Galindo, C., González, J. M., Alonso, A., Mas, J. R., Rodas, M., García, E., and Barrenechea, J. F. 1992. El metamorfismo en la Cuenca de los Cameros. Geochronología e implicaciones tectónicas. Geogaceta, 11: $22-25$.

Chiappe, L. M. 1997. Aves. In Currie, P. J. and Padian, K. (eds.), Encyclopedia of Dinosaurs. Academic Press, New York: 32-38.

Chiappe, L. M. 2002. Basal Bird Phylogeny, problems and solutions. In Chiappe, L. M. and Witmer, L. M. (eds.), Mesozoic Birds. University of California Press, Berkeley: 448-472.

Dalla Vecchia, F. M., Tarlao, A., Tunis, G., and Venturini, S. 2000. New Dinosaur track sites in the Albian (Early Cretaceous) of the Istrian Peninsula (Croatia). Mémoire di Scienze Geologiche, 52:193-292.

Dalla Vecchia, F. M., Tunis, G., Venturini, S., and Tarlao, A. 2001. Dinosaur track sites in the upper Cenomanian (Late Cretaceous) of Istrian Peninsula (Croatia). Bolletino della Società Paleontologica Italiana, 40:25-53.

Day, J. J., Upchurch, P., Norman, D. B., Gale, A. S., and Powell, P. 2002. Sauropod trackways, evolution, and behavior. Science, 296:165.

Elzanowski, A. 2002. Archaeopteygidae (Upper Jurassic of Germany). In Chiappe, L. M. and Witmer, L. M. (eds.), Mesozoic Birds. University of California Press, Berkeley: 129-159.

Farlow, J. O. 1992. Sauropod tracks and trackmakers: integrating the ichnological and skeletal records. Zubía, 10:89-138.

Foster, J. R., Lockley, M. G., and Brockett, J. 1999. Possible turtle tracks from the Morrison Formation of Southern Utah. Vertebrate Paleontology in Utah, 99:185-191.

Freyret, P. 1984. Les sédiments lacustres carbonatés et leurs transformations par émersion et pédogenése. Importance de leur identification pour les reconstitutions paléogéographiques. Bulletin des Centres de Recherches Exploration-Production Elf-Aquitaine, 8:223-247.

Fuentes, C. 1996. Primeras huellas de aves en el Weald de Soria (España). Nuevo icnogénero, Archaeornithipus y una nueva icnoespecie A. meijidei. Estudios Geológicos, 52:63-75.

Fuentes, C. and Meijide, M. 1996. Restos de pterosaurios en el "Weald" de Soria (España). Stvdia Geologica Salmanticensa, 32:15-22.

Gómez Fernández, J. C. and Meléndez, N. 1994. Estratigrafía de la "Cuenca de los Cameros" (Cordillera Ibérica Noroccidental, Norte de España) durante el tránsito Jurásico-Cretácico. Revista de la Sociedad Geológica de España, 7:121-139

Guiraud, M. 1983. Evolution tectono-sédimentaire du basin Wealden (Crétacé inférieur) en relais de décrochements de Logroño-Soria (NW Espagne). Université des Sciences et Techniques du Languedoc. Montpellier. $183 \mathrm{p}$.

Guiraud, M. and Seguret, M. 1985. A releasing solitary overstep model for the late Jurassic-early Cretaceous (Wealdian) Soria strike-slip basin (Northern Spain). In Strike Slip Deformation, Basin Formation and Sedimentation. Society of Economic Paleontologists and Mineralogists Special Publication, 37:159-175.

Kim, B. K. 1969. A study of several sole marks in the Haman Formation. Journal of the Geological Society of Korea, 5:243-258.

Lockley, M. G., Yang, S. Y., Matsukawa, M., Fleming, F., and Lim, K. 1992. The track record of Mesozoic birds: evidence and implications. Philosophical Transcriptions of the Royal Society of London B, 336:113-134.

Lockley, M. G., Logue, T. J., Schultz, R., Moratalla, J. J., Hunt, A. P., Robinson, J. W., and Wahl, B. 1995. The fossil trackway Pteraichnus is pterosaurian, not crocodilian: implications for the global distribution of pterosaur tracks. Ichnos, 4:7-20.
Lockley, M. G., Meyer, C., and Moratalla, J. J. 1998b. Therangospodus: trackway evidence for the widespread distribution of a Late Jurassic theropod with well-padded feet. Gaia, 15:339-358.

Lockley, M. G., Meyer, C. A., and Santos, V. F. 1996. Megalosauripus, Megalosauropus and the concept of Megalosaur Footprints. Museum of North Arizona Bulletin, 60:113-118.

Lockley, M. G., Meyer, C. A., and Santos, V. F. 1998a. Megalosauripus and the problematic concept of megalosaur footprints. Gaia, 15:313-337.

Martín-Closas, C. and Alonso, A. 1998. Estratigrafía y bioestratigrafía (Charophyta) del Cretácico inferior en el sector occidental de la cuenca de Cameros (Cordillera Ibérica). Revista de la Sociedad Geológica de España, 11:253269.

Mas, J. R., Alonso, A., and Guimerá, J. 1993. Evolución tectonosedimentaria de una cuenca extensional intraplaca: La cuenca finijurásica-eocretácica de Los Cameros (La Rioja-Soria). Revista de la Sociedad Geológica de España, 6:129-144.

Mennessier, G. and Calzada, S. 1985. Sobre dos Cassiopidae (Gastropoda) del Neocomiense Española. Munibe, 37:139-142.

Middleton, K. 2002. Evolution of the perching foot in theropods. Joumal of Vertebrate Paleontology, 22:88A.

Moratalla, J. J. 1993. Restos indirectos de dinosaurios del registro Española: Paleoicnología de la Cuenca de Cameros (Jurásico superior-Cretácico inferior) y Paleoología del Cretácico superior. PhD Thesis. Universidad Autónoma de Madrid, Spain. 728 p.

Moratalla, J. J. 2002. Cameros Basin megasequence (Spain): an overview on body and ichnological biodiversity from the European Cretaceous. Joumal of Vertebrate Paleontology, 22:90.

Moratalla, J. J. and Sanz, J. L. 1992. Icnitas aviformes en el yacimiento del Cretácico inferior de Los Cayos (Cornago, La Rioja, España). Zubía, 10:53160.

Moratalla, J. J. and Sanz, J. L. 1997. Cameros Basin Megatracksite. In Currie, P. J. and Padian, K. (eds.), Encyclopedia of Dinosaurs. Academic Press, New York: 87-90.

Moratalla, J. J., García-Mondéjar, J., Santos, V. F., Lockley, M. G., and Jiménez, S. 1994a. Sauropod trackways from the Lower Cretaceous of Spain Gaia, 10:75-83.

Moratalla, J. J., Sanz, J. L., and Jiménez, S. 1988a. Nueva evidencia icnológica de Dinosaurios en el Cretácico inferior de La Rioja (España). Estudios Geológicos, 44:119-131.

Moratalla, J. J., Sanz, J. L., and Jiménez, S. 1988b. Una icnita enigmática en el Cretácico inferior de La Rioja. IV Jornadas de la Sociedad Española de Paleontología. Salamanca. Resúmenes de las Comunicaciones. P: 65.

Moratalla, J. J., Sanz, J. L., and Jiménez, S. 1989. Icnitas de Dinosaurios. Estrato, 1:23-25.

Moratalla, J. J., Sanz, J. L., and Jiménez, S. 1992. Hallazgos de nuevos tipos de huellas en La Rioja. Estrato, 4:63-66.

Moratalla, J. J., Sanz, J. L., and Jiménez, S. 1994b. Dinosaur tracks from the Lower Cretaceous of Regumiel de la Sierra (province of Burgos, Spain): inferences on a new quadrupedal ornithopod trackway. Ichnos, 3:89-97.

Moratalla, J. J., Sanz, J. L., and Jiménez, S. 1997. Dinosaurios en La Rioja (Guía de yacimientos paleoicnológicos). Gobierno de La Rioja e Iberdrola. 175 pp.

Moratalla, J. J., Sanz, J. L., and Jiménez, S. 2000. Nuevos hallazgos de dinosaurios y pterosaurios en el Cretácico inferior de La Rioja. Estrato, 10:91-96.

Moratalla, J. J., Sanz, J. L., Jiménez, S., and Lockley, M. G. 1992. A quadrupedal ornithopod trackway from the Lower Cretaceous of La Rioja (Spain): inferences on gait and hand structure. Joumal of Vertebrate Paleontology, 12:150-157.

Norman, D. B. 1980. On the ornithischian dinosaur Iguanodon bernissasrtenssis from the Lower Cretaceous of Bernissart (Belgium). Mémoires Institut Royal des Sciences Naturelles de Belgique, 178: $103 \mathrm{p}$.

Norman, D. B. 1986. On the anatomy of (Ornithischia: Ornithopoda). Bulletin Institut Royal des Sciences Naturelles Belgique Science de la Terre, 56: 281-372.

Pascual, C. and Sanz, E. 2000. Huellas de pterosaurio en el Grupo Oncala (Soria, España). Pteraichnus palaciei-saenzi, nov. icnosp. Estudios Geológicos, 56:73-100. 
Platt, N. H. and Wright, V. P. 1991. Lacustrine carbonates facies models, facies distributions and hydrocarbon aspects. In Anadon, P., Cabrera, L., and Kelts, K. (eds.), Lacustrine Facies Analysis. Special Publication of the International Association of Sedimentologists, 13:57-74.

Salinas, F. J. and Mas, J. R. 1990. Estudio sedimentológico y tectosedimentario de la cubeta de Cervera del Río Alhama (La Rioja) durante la sedimentación del Grupo Urbión (Cretácico inferior). Estudios Geológicos, 46(3-4): 245-255.

Salomon, J. 1982a. Les formations continentales du Jurassique SupérieurCrétacé Inferieur (Espagne du Nord-Chaînes Cantabrique et NW Ibérique. Mémoires Géologiques de L'Université de Dijon, 6: $228 \mathrm{p}$.

Salomon, J. 1982b. El Cretácico inferior de Cameros-Castilla. In El Cretácico de España. Universidad Complutense de Madrid, Editorial de la Universidad Complutense de Madrid, Madrid: 345-387.

Santafé, J. V. and Casanovas, M. L. 1990. El món dels dinosaures. Diputació de Barcelona, $162 \mathrm{pp}$.

Santafé, J. V. and Casanovas, M. L. 1993. Los Dinosaurios en la Comunidad Valenciana. Generalitat Valenciana, 205 pp.

Santafé, J. V., Casanovas, M. L., Sanz, J. L., and Calzada, S. 1982. Morella y su fauna fósil. Publicaciones de la Diputación Provincial de Castellón de la Plana. $59 \mathrm{pp}$

Sanz, J. L. 1986. Nouveaux gisements de Dinosaures dans le Crétacé Espagnol. Les Dinosaures de la Chine à la France. Museum d'Histoire Naturella, Tolouse, France. pp. 81-88.

Sanz, J. L., Buscalioni, A. D., Casanovas, M. L., and Santafé, J. V. 1984a. The archosaur fauna from the Upper Jurassic/Lower Cretaceous of Galve (Teruel, Spain). In Reif, W.-E. and Westphal, F. (eds.), Third Symposium on Mesozoic Terrestrial Ecosystems. Attempto, Tübingen: 207-210.

Sanz, J. L., Buscalioni, A. D., Moratalla, J. J., Francés, V., and Antón, M. 1990. Los Reptiles Mesozoicos del Registro Español. Museo Nacional de Ciencias Naturales. C.S.I.C. Monografías. 78 pp.
Sanz, J. L., Casanovas, M. L., and Santafé, J. V. 1984b. Iguanodóntidos (REPTILIA, ORNITHOPODA) del yacimiento del Cretácico inferior de San Cristóbal (Galve, Teruel). Acta Geológica Hispánica, 19:171-176.

Sanz, J. L., Casanovas, M. L., and Santafé, J. V. 1984c. Restos autopodiales de Iguanodon (Reptilia, Ornithopoda) del yacimiento de Santa Bárbara (Cretácico inferior, Galve, provincia de Teruel, España). Estudios Geológicos, 40:251-257.

Sanz, J. L., Casanovas, M. L., and Santafé, J. V. 1982. Paleontología. In Santafé, J. V., Casanovas, M. L., Sanz, J. L., and Calzada, S. (eds.), Geología y Paleontología (Dinosaurios) de las Capas rojas de Morella (Castellón, España). pp. 69-169.

Sanz, J. L., Moratalla, J. J., and Casanovas, M. L. 1985. Traza icnológica de un dinosaurio iguanodóntido en el Cretácico Inferior de Cornago (La Rioja, España). Estudios Geológicos, 41:85-91.

Sanz, J. L., Moratalla, J. J., Rubio, J. L., Fuentes, C., and Meijide, M. 1997. Huellas de Dinosaurios de Castilla y León. Ed. Junta de Castilla y León. 87 pp.

Stokes, W. L. 1957. Pterodactyls tracks from the Morrison Formation. Joumal of Paleontology, 31:952-954.

Tischer, G. 1966. Uber die Wealden-Ablagerung und die Tektonik der östlichen Sierra de los Cameros in den nordwestlichen Iberischen Ketten (Spanien) Beihefte zum Geologischen Jahrburch, 44:123-164.

Tucker, M. E. and Wright, V. P. 1990. Carbonate Sedimentology. Blackwell Scientific Publications, Oxford: 482 pp.

Wilson, J. A. and Carrano, M. T. 1999. Titanosaur and the origin of "widegauge" trackways: a biomechanical and systematic perspective on sauropod locomotion. Paleobiology, 25:252-267.

Wright, J. and Lockley, M. G. 2001. Dinosaur and turtle tracks from the Laramie/Arapahoe formations (Upper Cretaceous), near Denver, Colorado, USA. Cretaceous Research, 22:365-376. 